\title{
O declínio da notícia no jornalismo pós- fordista dos conglomerados multimídia
}

\author{
Virginia Pradelina da Silveira Fonseca ${ }^{1}$ \\ UFRGS \\ virginia@ufrgs.br
}

\begin{abstract}
Resumo: Neste artigo, procura-se analisar algumas das formas pelas quais as mudanças macro-estruturais que vêm ocorrendo nas sociedades contemporâneas desde as últimas décadas do século $X X$, acentuando-se neste princípio de século XXI, manifestam-se no jornalismo produzido no âmbito das novas indústrias culturais - os conglomerados multimídia. Para isso, procura-se esclarecer, primeiramente, a compreensão que se tem do papel social do jornalismo. A seguir, toma-se o exemplo de Zero Hora, jornal de referência da Rede Brasil Sul de Comunicação (RBS), o grupo de mídia mais importante da região Sul do Brasil, com o objetivo de identificar elementos de manifestação da racionalidade pós-fordista no produto resultante da nova estrutura - flexível - da organização, da produção e do trabalho. Por fim, sugere-se a hipótese de que uma nova concepção está a se delinear através de novos critérios e valores de noticiabilidade.
\end{abstract}

Palavras-chave: jornalismo - conglomerados multimídia - pós-fordismo

1 Doutora em Comunicação e Informação, professora, pesquisadora e orientadora no Programa de Pós-Graduação em Comunicação e Informação da Universidade Federal do Rio Grande do Sul. Vencedora do Prêmio Capes de Tese em 2006 na área de Ciências Sociais Aplicadas I.. 


\begin{abstract}
This article aims at analysing some of the ways through which macrostructural changes which have been happening in modern societies since the last decades of the XX century, and which have accelerated in this early XXI century, influence the journalism produced within the new cultural industries - the multimedia conglomerates. Thus, it tries and shed some light firstly on the understanding that one has of the social role played by journalism. Next, one takes as an example Zero Hora, a newspaper which has become standard within Rede Brasil Sul de Comunicação (RBS), the most important media group in the South of Brazil, the purpose here being to identify elements that represent the post-fordism racionality on the resulting product of the new-flexible - structure of the organization, of the production and of the work. Finally, one puts forward the hypothesis that a new conception is being drawn up through new criteria and values of newsworthiness.
\end{abstract}

Key-words: journalism - multimedia conglomerates - post-fordism

Resumen: En este artículo, se busca analizar algunas de las formas que hacen que los cambios de las macroestructuras que vienen ocurriendo en las sociedades contemporáneas desde las ultimas décadas del siglo $X X$, acentuándose en este principio del siglo XXI, se manifiesten nel periodismo producido al alcance de las nuevas industrias culturales - los conglomerados multimedias. Para esto, se busca el esclarecimiento, primero, para la comprensión que si tiene del papel social del periodismo. Para seguir, se toma el ejemplo de Zero Hora, periódico referencia de la Rede Brasil Sul de Comunicação (RBS), el grupo de medios más importantes de la región del sur del Brasil, con el objetivo de identificar elementos de la manifestación de la racionalidad posfordista en del producto resultante de la nueva estructura flexible - de la organización, de la producción y del trabajo. Finalmente, se sugiere la hipótesis de que un nuevo concepto se esta a delinear partiendo de nuevos criterios y valores de noticiabilidade.

Palabras clave: periodismo -- conglomerados multimedias - posfordismo

Résumé: Dans cet article, on cherche à analyser des façons pour lesquelles les changements macrostructurels, qui se passent dans les sociétés contemporaines dès les dernières décennies du XXe siècle et qui s'accentuent en ce début du XXIe siècle, se manifestent dans le journalisme produit dans le domaine de nouvelles industries culturelles - les conglomérats multimédias. Pour autant, on cherche à éclairer, premièrement, la compréhension que l'on a sur le rôle social du journalisme. Ensuite, on prend l'exemple de Zero Hora, le journal de référence de la Rede Brasil Sul de Comunicação (RBS), le groupe de média le plus important de la région Sud du Brèsil, avec le but d'identifier d'éléments de manifestation de la rationalité post-fordiste dans le produit résultant de la nouvelle structure - flexible - de l'organisation, de la production et du travail. À la fin, on suggère l'hypothèse qu'une nouvelle conception est en train de se former par de nouveaux critères et valeurs d'événementialité.

Mots-clé : journalisme - conglomérats multimédias - post-fordisme. 


\section{Introdução}

Neste artigo, procura-se analisar algumas das formas pelas quais as mudanças macro-estruturais que vêm ocorrendo desde as últimas décadas do século XX, acentuandose sobremaneira neste princípio de século XXI, manifestam-se no jornalismo produzido no âmbito das indústrias culturais contemporâneas - os conglomerados multimídia.

Numa análise mais ampla ${ }^{2}$, sustenta-se a hipótese de que as transformações nas estruturas organizacionais da mídia, nas rotinas de produção e na organização do trabalho dos jornalistas ao longo do tempo obedecem a condicionamentos específicos das etapas do processo de acumulação capitalista e dos respectivos regimes de acumulação dominantes em cada período. Acredita-se que, subjacente a cada modelo econômico hegemônico, prevalece uma concepção de jornalismo. Portanto, à medida que emerge um novo ciclo no capitalismo monopólico, o da globalização flexível, uma nova concepção estaria a se configurar - à espera de identificação e caracterização.

Para empreender essa reflexão, procura-se esclarecer, primeiramente, a compreensão que se tem do papel social do jornalismo. Argumenta-se que, modernamente, o jornalismo define-se pelo conceito de notícia. A seguir, toma-se o exemplo de Zero Hora, jornal de referência da Rede Brasil Sul de Comunicação (RBS), o grupo de mídia mais importante da região Sul do Brasil, com o objetivo de, ao descrevê-lo, identificar elementos de manifestação da racionalidade pós-fordista ${ }^{3}$ no produto resultante da nova estrutura organizacional, da produção e do trabalho. Por fim, sugere-se a hipótese de que uma nova concepção está a se delinear. A nova tendência seria caracterizada pelo declínio da notícia como expressão do jornalismo em favor de valores como informação, prestação de serviço e entretenimento (fait divers). Essa tendência estaria em emergência em alguns conglomerados de mídia plenamente submetidos à racionalidade da etapa global do capitalismo, mais empenhados em preservar a organização como ente econômico que na

\footnotetext{
${ }^{2}$ Este artigo reflete parte de pesquisa realizada como tese de Doutorado no Programa de PósGraduação em Comunicação e Informação (PPGCOM) da Universidade Federal do Rio Grande do Sul sob orientação do Prof. Dr. Sérgio Capparelli.

${ }^{3}$ Por Fordismo entende-se o regime de acumulação hegemônico no período pós-Guerra nos países capitalistas avançados, caracterizado pelo controle do Estado e pelas grandes corporações. Forma de organização da produção em grande escala para consumo de massa (HARVEY, 2001).
} 
qualificação da informação jornalística, reduzindo, conseqüentemente, o papel do jornalismo como fonte de conhecimento/esclarecimento do público.

Com isso, procura-se relacionar o modo de regulamentação dominante - as normas, os hábitos, as leis, os comportamentos que dão coerência ao esquema de reprodução do regime de acumulação (HARVEY, 2001) - à tendência estruturada no seio das transformações determinadas pelo novo capitalismo e pelas novas tecnologias de comunicação e informação.

\section{A notícia como expressão do Jornalismo}

Como pressuposto, compartilha-se com Rüdiger (2003) e Genro Filho (1989) a compreensão de que é necessário distinguir entre jornalismo e imprensa. Para o primeiro, jornalismo é uma atividade social constituinte do processo de formação da opinião pública, dotada de conceito variável conforme o período, e que pode se estruturar de modo regular nos mais diversos meios de comunicação. O jornalismo é, assim, elemento da esfera pública. Não se confunde com imprensa, que, conforme o segundo autor, é o corpo material do jornalismo, sua base tecnológica (jornal, rádio, tv, web) indispensável à divulgação, capaz de multiplicar e transportar a mesma informação em proporções de espaço e tempo radicalmente diferentes da comunicação interpessoal direta. Dessa forma, como observa Rüdiger (2003), a existência da imprensa não é suficiente para garantir a presença de uma concepção de jornalismo.

O jornalismo de que trata esta análise é aquele representado pela empresa capitalista: "jornalismo informativo, tomado como modelo do próprio conceito de jornalismo" (Genro Filho, 1989, p. 23). Não é o jornalismo cívico, comunitário, popular, sensacionalista ou cidadão, nem aquele que busca de todas as formas manter algum grau de autonomia em empresas públicas. Como Marcondes Filho, acredita-se que é na empresa capitalista que se mantêm "as características originais da atividade jornalística: a busca da notícia, o 'furo', o caráter de atualidade, a aparência de neutralidade, [...], o caráter 'libertário e independente."” (MARCONDES FILHO, 1989, p.65).

Ao vincular jornalismo e empresa privada, Marcondes Filho (1989) não deixa de observar que, assim como o funcionamento econômico é regido pelo laissez-faire, também a 
atividade jornalística reflete o jogo de forças presente na disputa política. Com isso sustenta que, sob a etapa concorrencial do capitalismo, prevalece a aparência pluralista da imprensa jornalística; sob a monopólica, a expressão concentra-se e restringe-se aos setores monopolistas da informação e da opinião na sociedade.

O jornalismo assim compreendido não constitui fenômeno recente. Suas origens remontam ao século XVII e é tributário dos ideais iluministas da Revolução Francesa. Integra o processo de ascensão da burguesia e de estruturação da esfera pública, tema suficientemente abordado por Habermas (2003), para quem a atividade passou a existir a partir do momento em que as notícias passaram a ser produzidas no âmbito de empresas privadas, e quando os noticiários tornaram-se regulares, periódicos e acessíveis ao público em geral.

Moretzsohn explica que, apesar das raízes iluministas que fornecem os princípios do jornalismo, até a Revolução Francesa a imprensa não alcançara prestígio como instrumento de expressão de idéias. "Valorizados eram os livros e brochuras". Segundo a autora, foi a precipitação dos acontecimentos de 1789 que deu à imprensa, na França, o status obtido na independência americana, "como instrumento fundamental para o esclarecimento das multidões" (MORETZSOHN, 2002, p. 42).

Como negócio de empresa privada, voltado para o público em geral, para "as massas", o jornalismo começou a se estruturar apenas no século XIX, depois de criadas as condições materiais e técnicas para a produção em grande escala. Nas últimas décadas, já tomava forma nos grandes conglomerados que começavam a se organizar.

No Brasil, a imprensa jornalística de caráter empresarial tem suas raízes no final do século XIX, mas se consolida, como tal, no século XX. A associação entre jornalismo e notícia se faz mais evidente a partir dos anos 1960, quando um movimento modernizador atinge a maioria dos principais jornais do País, introduzindo a concepção americana de objetividade e adotando os primeiros princípios de gerenciamento científico - os primórdios do fordismo na mídia impressa nacional.

Mesmo que, particularmente dessa fase em diante, o jornalismo cada vez mais se institucionalize como negócio, e a notícia como mercadoria, parece-nos ter prevalecido ao 
longo o tempo o princípio de que cabe ao jornalismo contribuir para o esclarecimento do cidadão. Esse princípio estaria presente, conforme Moretzsohn (2002), nos ideais de objetividade e suposto poder de "verdade" contido nos fatos noticiados. Sobreviveria nos manuais de redação, nas declarações de princípios dos jornais, em alguns estudos acadêmicos e até em documentos que ratificam o papel "sagrado" da imprensa. Tais ideais teriam inspirado alguns dos princípios fundamentais da atividade jornalística, como a Teoria da Responsabilidade Social, fundada na idéia de que o público tem o "direito de saber", o que remeteria à classificação de "Quarto poder".

[...] Acima das contradições da sociedade, sem interesses a defender, capaz de falar em nome de todos [...]. São princípios desenvolvidos no contexto da sociedade americana, mas cujo reconhecimento transcende essa particularidade, não só porque [...] vinculam-se aos postulados básicos do iluminismo, como porque foram adotados pela imprensa ocidental em geral, e é em torno deles que se procura formular uma teoria do jornalismo (MORETZSOHN, 2002, p. 56).

Embora crítica quanto às possibilidades de objetividade e verdade no jornalismo, a autora não deixa de reconhecê-los como princípios herdeiros da tradição iluminista. São esses postulados contidos na informação jornalística, cuja pertinência não nos cabe discutir no âmbito desta pesquisa, que nos permitem conceber jornalismo como notícia.

Os estudos de Chaparro também nos permitem sustentar que a notícia é a expressão do jornalismo. Seu papel seria o de fazer um relato verdadeiro e dar a explicação pertinente dos fatos de relevância social. Para o autor, o jornalismo é "o elo que, nos processos sociais, cria e mantém as ações viabilizadoras do direito à informação" (CHAPARRO, 1994, p. 108).

Para sustentar a hipótese de que a cada etapa do capitalismo, e a cada regime de acumulação dominante na organização da produção, predomina uma concepção de jornalismo, argumenta-se com a prevalência da notícia como sua expressão durante todo o período fordista e parte do pós-fordista, apesar do aprofundamento do seu caráter de mercadoria. Diz-se em favor dessa tese que, apesar da mercantilização crescente, vinha prevalecendo um esforço em delimitar espaços editorias e publicitários, em preservar a neutralidade, ainda que aparente, a que fazem referência Marcondes Filho (1989), Barros 
Filho (1995) e Moretzsohn (2002). O jornal, mais que qualquer dos outros meios de comunicação, define-se, tradicionalmente, pelo gênero informativo. A essência do veículo é sua editorialização. Quando o leitor adquire o exemplar na banca ou contrata a assinatura, está à procura de notícias, diferentemente de rádio e de televisão, e mais recentemente de internet, a quem o receptor recorre não necessariamente em busca de informação jornalística, mas de informação, entretenimento ou serviço.

Não nos cabe aqui fazer uma discussão exaustiva sobre o conceito de notícia. Em pesquisa sobre a imposição do chamado "tempo real" no jornalismo on-line, Moretzsohn (2002) dedica boa parte de seu estudo a sistematizar definições, desde as contidas em manuais de redação até as elaboradas no interior de hipóteses de pesquisa, como Nensmaking, e de perspectivas teóricas críticas, como a Economia Política da Comunicação. Acrescenta-se, entretanto, a título de contribuição, a definição de Robert Darnton: "toda notícia que couber, a gente publica". O historiador adota como conceito expressão que viu em grafite na parede da sala de imprensa de um delegacia em Manhattan, durante breve período em que se experimentou como repórter do The Times. Ele acha que o grafite queria dizer que os artigos só são publicados no jornal se tiver espaço ${ }^{4}$, mas acredita que também poderia estar expressando uma verdade mais profunda: que "as matérias jornalísticas precisam caber em concepções culturais prévias relacionadas com a notícia" (Darnton, 1995, p. 96). Moretzsohn (2002) considera essa uma das definições de melhor síntese e identifica nela uma aproximação com o conceito de habitus ${ }^{5}$, de Bourdieu.

Mais do que a interferência de interesses políticos e econômicos, equivocadamente vistos como 'estranhos ao jornalismo' (como se o jornalismo pudesse existir numa esfera ideal, independente da teia de interesses do poder), é o habitus que proporciona o estabelecimento de rotinas que levam a notícia a ser procurada ali onde ela é sempre encontrada, o que cria um círculo vicioso que envolve a relação com as fontes (MORETZSOHN, 2002, p. 66).

\footnotetext{
${ }^{4}$ O grafite apenas reproduzia o lema do New York Times - All the News Thats's Fit to Print.

${ }^{5}$ Habitus, para Bourdieu (1990), são as estruturas mentais através das quais se apreende o mundo social, o produto da interiorização das estruturas do mundo social. Harvey (2001) faz referência a esse conceito ao discorrer sobre o processo de constituição dos regimes de acumulação e dos modos de regulamentação que lhes são inerentes.
} 
Com isso, a autora conclui ser impossível chegar-se a um conceito de notícia adotando apenas critérios internos à profissão.

Deixando-se de lado as definições teóricas de estudos acadêmicos, procura-se retomar alguns critérios de definição de ordem pragmática, amplamente aceitos e adotados como habitus no mundo do trabalho, no campo profissional. Essas definições estão presentes nos manuais de redação a partir da enunciação de critérios de seleção. O Manual da Redação da Folha de São Paulo (2001) relaciona os seguintes critérios para definir a importância da notícia: ineditismo, improbabilidade, interesse, apelo (curiosidade que possa despertar), empatia (identificação com personagens e situações) e proximidade.

Outros manuais, assim como autores de obras direcionadas à prática, elencam alguns outros critérios, como impacto, exotismo, etc. De qualquer forma, trata-se de variações que podem muito bem ser sintetizadas nas cinco características clássicas da notícia formuladas por Erbolato (1991): ineditismo, veracidade, atualidade, objetividade e interesse público. As características nos permitem relembrar que toda notícia é informação, mas nem toda informação é notícia, ou que nem todo fato social é fato jornalístico, cabendo ao jornalista fazer, entre a superabundância de fatos sociais, a sua seleção. "Os fatos jornalísticos são um recorte no fluxo contínuo, uma parte que [...] é separada arbitrariamente do todo" (GENRO FILHO, 1989, p. 188).

Dentre a gama de tentativas acadêmicas e profissionais de definição de notícia, parece-nos que sobressai um atributo: o do interesse público. Chaparro (1994), depois de extenso levantamento, conclui que a palavra interesse é a que mais se repete nas definições do que seja jornalismo, simbolizado na notícia.

A atividade jornalística deve ser avaliada e avalizada pelas razões do interesse público, parâmetro gerador dos critérios jornalísticos de valoração da informação. E quanto mais vigorosos forem os atributos de relevância social da informação, maior será a dimensão do interesse público atendido" (CHAPARRO, 1994, p. 118).

É a concepção de que notícia é a expressão do jornalismo - e que esta obedece fundamentalmente ao critério/valor "interesse público" - que faz com que se atribua a essa 
atividade o papel de esclarecimento da sociedade quanto aos acontecimentos (fatos sociais) efetivamente relevantes. E esse é o critério que nos parece estar entrando em declínio.

A descrição do caderno principal do jornal Zero Hora, que se faz a seguir, além de procurar identificar elementos caracterizadores da flexibilidade pós-fordista no "produto", é atenta também para os critérios de noticiabilidade adotados no periódico gaúcho.

\section{O jornal pós-fordista ${ }^{6}$ : flexível e segmentado}

Dentre os fatores apresentados no Congresso Mundial de Jornais, realizado na Turquia em 20047, como responsáveis pelo sucesso do jornal da RBS, constou o seu conteúdo editorial. Na parte que lhe coube na exposição do 'case' Zero Hora, o diretor de redação, Marcelo Rech, atribuiu o êxito da política editorial à observância do que chamou de quatro pilares básicos: a) o tratamento de assuntos que afetam a vida do leitor; b) a valorização de diferentes pontos de vista em matérias e colunas; c) o esforço de edição para apresentar ao leitor um jornal ao mesmo tempo profundo e fácil de ler; e d) a interatividade com os leitores, representada por seções como 'Sobre ZH', da página 2, e a editoria 'Atendimento ao Leitor'.

Esses "pilares" serão retomados mais adiante, como critérios de noticiabilidade adotados no periódico, que estariam contribuindo para a estruturação de uma nova concepção de jornalismo. A idéia é problematizar algumas questões que permitam sustentar a hipótese da emergência de uma nova tendência na seleção dos conteúdos, menos relacionada à notícia e mais à informação, à prestação de serviço e ao entretenimento. Antes, julga-se necessário descrever e analisar as características gerais do produto que sai da linha de montagem flexível da era pós-fordista de produção.

\footnotetext{
${ }^{6}$ Por pós-fordismo entende-se o regime de acumulação que se estrutura nos países capitalistas avançados a partir da crise do capitalismo internacional dos anos 1970. Em oposição à rigidez fordista, caracteriza-se pela flexibilidade dos processos de produção, da regulamentação, do gerenciamento e do consumo, assim como pela redução da influência do Estado. Fordismo e pós-fordismo são formas de organização da produção típicos da etapa monopólica do capitalismo.

$757^{\circ}$ Congresso Mundial de Jornais, evento realizado em Istambul em junho de 2004, promovido pela Associação Mundial de Jornais (WAN), reunindo publishers, editores e proprietários de diários do mundo interiro.
} 
Para isso, descrevem-se as seções do Caderno Principal e o processo de compartilhamento de conteúdos do caderno principal de uma semana: de 25 de outubro (segunda-feira) a 31 de outubro (domingo) de 2004.

Apesar de o período coincidir com a última semana anterior à realização do segundo turno das eleições municipais em Porto Alegre, a escolha do período foi aleatória. Acredita-se que o caráter atípico das coberturas eleitorais não compromete a análise na medida em que esta não se refere às rotinas produtivas e à organização do trabalho ${ }^{8}$, que certamente se alteraram excepcionalmente em razão do evento, mas se limita ao conteúdo geral manifesto nas edições, e não ao conteúdo da cobertura política.

\section{Caderno principal}

O jornal Zero Hora da fase pós-fordista é mais flexível e mais segmentado em relação ao jornal massivo do período fordista. É composto do caderno principal e do chamado Segundo Caderno, com circulação regular e fixa na semana, de segunda a domingo, e de cadernos segmentados, com circulação variável. Alguns saem uma vez por semana, em dias fixos, outros mensalmente. A flexibilidade dos cadernos decorre do fato de entrarem e saírem de circulação com facilidade, dependendo da emergência de determinados temas e das condições do mercado, ou do que o diretor de redação define como "empuxe", isto é, da capacidade de atrair leitores e, conseqüentemente, anunciantes interessados nesses leitores/ clientes.

Quanto ao caderno principal, o tamanho de cada edição é definido em função dos fatores necessidade editorial e publicidade. No período analisado, tinha entre 40 a 64 páginas, dependendo da quantidade de anúncios. Em situações excepcionais, pode ser ampliado - já teve 88 e até 96 páginas. A ampliação se justifica pela necessidade de acolher toda a demanda publicitária sem reduzir espaço editorial. "Em notícias de grande envergadura, que exigem mais espaço que o habitual, o jornal acrescenta páginas, por vezes até cadernos extras [como no primeiro turno da campanha eleitoral de 2004], de modo a atender ao interesse do leitor" (Marcelo Rech, ZH, 24/10/2004, p. 3).

\footnotetext{
8 A observação das rotinas de produção e da organização do trabalho jornalístico, que integra a mesma pesquisa, foi realizada entre os dias 16 e 20 de novembro de 2004.
} 
Quando se questiona a influência dos anunciantes sobre o conteúdo editorial, Rech sustenta que os anunciantes exercem três papéis em relação ao jornal: a) oferecer informação e serviços adicionais aos leitores; b) subsidiar o preço da assinatura ou da venda avulsa; c) assegurar a independência do veículo. Segundo ele, ZH tem uma "robusta" e diversificada carteira de anunciantes e nenhuma origem publicitária é superior a $2 \%$ da receita total obtida com anúncios, o que reduziria o poder de pressão de um determinado anunciante. $\mathrm{O}$ diretor de redação acredita que veículos de comunicação com essa condição têm saúde financeira para rejeitar pressões e garantir a seus públicos um noticiário definido unicamente pelos interesses jornalístico e editorial. "Assim, cria-se um círculo virtuoso: o veículo preserva a sua credibilidade, amplia seu alcance, oferece mais e melhor retorno aos anunciantes e, graças à robustez econômica, assegura qualidade e independência aos seus leitores. [...]. Essa é a fórmula do contínuo sucesso de Zero Hora" (Marcelo Rech, 24/10/2004, p. 3).

Quanto aos conteúdos jornalísticos do caderno principal, distribuem-se pelas seguintes seções e editorias: Palavra do Leitor, Informe Especial, Reportagem Especial, Política, Editoriais, Opinião, Economia, Indicadores, Mundo, Geral, Polícia, Esportes, Tempo, Almanaque Gaúcho e Memória.

No caderno principal, as matérias distribuídas da forma clássica, por editorias, dirigem-se ao público em geral e via de regra são as mesmas independentemente da região de circulação do jornal. Uma página diária, contudo, tem conteúdo distinto. "Pelo Rio Grande/Metropol" é a definição da seção que reúne notícias de interesse exclusivo do público da região metropolitana de Porto Alegre; e "Pelo Rio Grande", da mesma forma, matérias sobre eventos de interesse do interior do estado. Os leitores do interior obtém um espaço um pouco maior de informação sempre que for veiculado anúncio restrito à região metropolitana. Nesse caso, os exemplares da primeira edição, enviados para o interior, apresentam notícias na página onde, na região metropolitana, encontra-se o anúncio.

Essa flexibilidade também pode ocorrer na primeira página, na contracapa, ou mesmo nas páginas 4 e 5, sempre reservada a uma reportagem especial, dependendo da importância da notícia. No dia $1^{\circ}$ de novembro de 2004, logo após o segundo turno das 
eleições municipais, circularam quatro capas com manchetes que procuravam valorizar os resultados por região, da maneira mais próxima possível do leitor. A manchete da primeira edição, que circulou em grande parte do interior do estado, foi "PT perde em Porto Alegre, Pelotas e Caxias do Sul". Na região de Caxias do Sul, anunciava a eleição de José Ivo Sartori, do PMDB; na região de Pelotas, de Bernardo de Souza, do PPS; e na região metropolitana, a vitória de José Fogaça, do PPS, em Porto Alegre, antecedida de uma linha de apoio ressaltando a derrota do PT, partido que comandava as prefeituras nas três cidades onde houve segundo turno. As chamadas de capa da edição dirigida à região metropolitana informavam os resultados eleitorais nas três maiores cidades do Rio Grande do Sul e o resultado em São Paulo.

Na edição do dia 11 de novembro de 2004, Zero Hora conseguiu incluir como manchete a informação sobre a morte do líder palestino Yasser Arafat, ocorrida às 2h08min da madrugada daquele dia, em Paris. A notícia pode ser incluída porque a editoria de Esportes aguardava o resultado de um jogo que transcorria após a meia-noite para fechar a terceira edição, que circularia, em razão do horário, apenas em algumas regiões de Porto Alegre ${ }^{9}$. Além da morte de Arafat, a última edição acabou noticiando também os estragos provocados pela chuva e as enxurradas que alagaram as ruas da capital naquela madrugada.

Os exemplos nos permitem concluir que o jornal consegue conciliar redução de tempo, compressão de espaço e atualidade jornalística - uma proeza para mídia impressa, que têm características de produção e difusão diferente das mídias eletrônicas, mais instantâneas. Isso é possível pela flexibilidade de sua linha de produção e pelo uso de tecnologias. Como estratégia de marketing, sempre que consegue superar as dificuldades inerentes à sua própria estrutura e publica alguma notícia de impacto ocorrida fora do seu tempo regular de produção, o jornal não perde a oportunidade da auto-referência e ressalta o feito na edição do dia seguinte ${ }^{10}$.

\footnotetext{
${ }^{9}$ Os jornalistas brincam que essa edição circula na "Grande Azenha", bairro da capital onde fica a sede do jornal.

${ }^{10}$ Como comprovam a nota do Informe Especial, na página 2 da edição de 12/11/2004, e a seção Cartas ao Leitor da edição de 7/11/2004. "Na segunda-feira posterior ao segundo turno
} 


\section{Compartilhamento de conteúdos}

Uma forma de flexibilidade que também representa superação de limites de espaço e de tempo é o compartilhamento de conteúdos. Tido como uma das etapas mais importantes no processo de estruturação multimídia, e fator de redução de custos, o compartilhamento vem sendo praticado e incentivado entre todos os veículos e profissionais da RBS. Além da pauta, que depois de consolidada é disponibilizada em rede para todas as redações dos veículos da organização, grande parte dos conteúdos editoriais são comuns entre a rede de jornais, entre alguns jornais, entre os jornais e as rádios, entre as rádios e as emissoras de tv, entre as rádios, a tv, os jornais e o ClicRBS, entre cadernos, entre editorias, entre seções, etc. A flexibilidade é tão ampla que permite as mais diversas combinações.

Apenas para exemplificar, os conteúdos das editorias de Polícia são comuns entre Zero Hora e Diário Gaúcho ${ }^{11}$; os do caderno DonnaZH, com algumas modificações locais, transformam-se em DonnaDC no Diário Catarinense ${ }^{12}$; a seção Indicadores Econômicos é a mesma em toda a rede de jornais; os resumos das novelas, o horóscopo, o principal editorial e alguns colunistas, idem. A lógica prevalecente é: sempre que um conteúdo for do interesse comum a leitores, ouvintes, telespectadores ou usuários, e sempre que o conteúdo se adequar às especificidades da outra mídia, deve ser compartilhado - de textos jornalísticos a seções de entretenimento ou prestação de serviços.

Com essa perspectiva, a empresa promoveu um concurso entre os jornalistas dos seus veículos - do Rio Grande do Sul, Santa Catarina e Brasília - com o objetivo de incentivar e valorizar o investimento destes na concepção multimídia. Das 11 categorias previstas para o $1^{\circ}$ Prêmio RBS de Jornalismo ${ }^{13}$, cujos vencedores foram conhecidos e

das eleições, Zero Hora circulou com quatro capas diferentes, com o objetivo de valorizar os resultados da maneira mais apropriada possível para leitores de distintas regiões do Estado [...]." (ZH, 07/11/2004, p. 3).

${ }^{11}$ Jornal popular do mesmo grupo, voltado para as classes C, D e B sem hábito de leitura.

12 Jornal de referência do grupo RBS no estado de Santa Catarina.

13 As categorias da primeira edição do concurso foram: experiência multimídia, relação comunitária, edição de jornal, edição de tv, edição de rádio, edição de Internet, gente comum, pauta criativa, inovação editorial, experiência de vínculo entre on-line e veículo tradicional e interatividade com o público ( $\mathrm{ZH}, 08 / 11 / 2004$, p. 25). 
premiados durante um evento realizado em Porto Alegre, em novembro de 2004, pelo menos duas valorizam especificamente os trabalhos e as iniciativas nessa direção: experiência multimídia (trabalho de cobertura amplificada entre jornal, tv, rádio e internet, em que uma mesma matéria é veiculada em todos os veículos da RBS) e experiência de vínculo entre on-line e veículo tradicional (que valoriza a utilização do $\mathrm{ClicRBS}^{14}$ como forma de ampliar e qualificar os conteúdos de jornal, rádio e TV ${ }^{15}$ ).

O investimento da empresa no compartilhamento de conteúdos, que integra o processo de reestruturação produtiva, obedece à mesma lógica de aceleração do tempo de giro do capital. Significa compressão espaço-temporal para o produtor de notícias (emissor) e para o leitor (receptor), o que obedece a razões de natureza jornalística. Mas representa, sobretudo, uma forma de "enxugamento" - de redução de custos com recursos humanos e com a própria produção.

Quando a mídia impressa, pela flexibilidade da sua estrutura e organização, consegue conciliar fatores à primeira vista contraditórios, como a redução do tempo de produção e a preservação da atualidade jornalística, tem-se a configuração do que Harvey (2001) chama de compressão espaço-temporal, uma das principais características do regime de acumulação flexível e da pós-modernidade. A compressão espaço-temporal significaria uma nova rodada, um aprofundamento da compressão do tempo e do espaço que já ocorria sob o fordismo, e que obedece à lógica da aceleração do tempo de giro do capital. "Como há limites para a acumulação e para o giro de bens físicos [...], faz sentido que os capitalistas se voltem para o fornecimento de serviços bastante efêmeros em termos de consumo" (HARVEY, 2001, p. 258).

O conceito de Castells (2000a) para o mesmo fenômeno é bastante esclarecedor. O autor denomina a temporalidade dominante na sociedade contemporânea de "tempo intemporal". Partindo do conceito de Leibniz, para quem tempo é a ordem de sucessão das coisas, o sociólogo explica que "tempo intemporal" é a designação de uma espécie de

\footnotetext{
14 Portal de acesso a Internet e site de conteúdos do grupo RBS.

15 A RBS segue uma tendência crescente na mídia jornalística nacional, de remeter para o site eletrônico da empresa o leitor ou telespectador que deseje ter mais informações sobre um determinado assunto. Ex: "saiba mais sobre como enfrentar a crise dos 25 anos no site www.clicrbs.com.br"'.
} 
embaralhamento do presente, do passado e do futuro, proporcionado pelo tempo instantâneo das redes, que é diferente do tempo do quotidiano.

Quando se procura analisar a questão do tempo e do espaço no jornalismo impresso à luz do conceito de Castells, tem-se a representação da compressão referida por Harvey (2001). A flexibilidade da sua estrutura de produção e de circulação, assim como as tecnologias de comunicação e informação, permitem a Zero Hora enfrentar e superar alguns limites de tempo e de espaço cruciais no jornalismo - em relação ao tempo e ao espaço onde são gerados os acontecimentos/notícia e em relação ao tempo e ao espaço onde são recebidos/consumidos esses acontecimentos.

Contrariamente, apesar da possibilidade de conciliação entre esses fatores, supostamente conflitivos, como os exemplos descritos comprovam, em outras situações o jornal deixa de cumprir um dos atributos do jornalismo - a atualidade - por razões de ordem empresarial. É o que ocorre sempre que antecipa o deadline para atender às demandas dos anunciantes. A edição de domingo é exemplar.

Constituída basicamente de matérias "frias", cuja "durabilidade" se mantém por um período maior, e produzida ao longo da semana, a edição dominical é fechada às 9h30min da manhã de sábado, e impressa por volta do meio-dia, para circulação à tarde. Esses horários obedecem a critérios unicamente comerciais, para atender a interesses de anunciantes e leitores de classificados, e implicam a extensão da jornada de trabalho de repórteres e editores pela madrugada. O horário de fechamento, muito antecipado em relação ao aceitável para um diário, significa que todo o fato jornalístico ocorrido a partir desse horário não constará da edição de domingo, o que constitui um evidente prejuízo para o leitor e a configuração da subordinação do jornalismo à lógica da empresa. Confirma-se assim o fenômeno do assujeitamento, apresentado por Taschner (1992), como uma das características do jornalismo nas indústrias culturais.

Com isso se conclui que o atributo jornalístico da informação só se impõe quando não contraria o interesse comercial; e mais, quando pode se transformar em argumento nas estratégias de venda do produto.

\section{Declínio da notícia como expressão do jornalismo}


Retomam-se agora os "pilares" editoriais apresentados pelo diretor de redação de Zero Hora no congresso internacional da Turquia como sintomas do surgimento de uma nova concepção de jornalismo, menos vinculada à notícia e mais próxima da prestação de serviços, da informação e do entretenimento.

No congresso da WAN, em Istambul, o executivo do periódico gaúcho enumerou quatro fatores que julga explicarem o sucesso de Zero Hora, do ponto de vista editorial. Esses fatores são aqui tomados como critérios de seleção das notícias e de política editorial: assuntos que afetam a vida do leitor, valorização de diferentes pontos de vista (em matérias e colunas), profundidade e facilidade de leitura, interatividade com o leitor. A esses, acrescentam-se outros, apresentados pelo mesmo jornalista em palestra para um grupo de editores e contatos publicitários no interior de São Paulo, em 2004. Na oportunidade, Marcelo Rech, que é também o diretor editorial da rede de jornais da RBS, relacionou uma espécie de 'dez mandamentos' a serem observados por quem deseje sucesso "no ramo": 1) ser regional; 2) ser bairrista; 3) evitar o excesso de opinião; 4) selecionar bem os temas; 5) fazer textos curtos; 6) dar o máximo de informação no mínimo de espaço; 7) priorizar o noticiário local; 8) manter a independência; 9) atender bem o leitor; 10) ser jovem (Revista Imprensa, no 195, p. 60-61).

Os fatores de política editorial apresentados nesses dois eventos, complementados pela análise do produto jornal e pelos dados captados durante o período de observação na redação do jornal, parecem nos fornecer elementos suficientes para justificar a hipótese aqui levantada. Alguns desses fatores têm caráter jornalístico, como a valorização de todos os pontos de vista, a abordagem de assuntos próximos à vida do leitor, o cuidado na seleção de notícias, a independência. Outros, porém, precisam ser mais bem analisados.

Para iniciar, tome-se duas recomendações: ser regional e bairrista. Para justificá-las, o jornalista argumenta que não adianta copiar os grandes jornais - as pautas devem ser totalmente voltadas para o quotidiano da região. "Quando um assunto nacional é inevitável, procure abordá-lo sob a perspectiva local" (Rech apud Revista Imprensa, n 195, p. 60). Quanto ao bairrismo, o diretor de redação fornece um exemplo prático. "Se um avião caiu longe de sua região e não houve nenhum sobrevivente, a primeira pergunta que 
deve ser feita é: quantos habitantes de sua cidade estavam a bordo? Nenhum? Então a história deve se resumir a uma nota. Caso contrário, o assunto passa a ser manchete" (idem).

Do primeiro caso, é-se levado a inferir que um jornal que prioriza sobretudo o fato jornalístico regional, e o ponto de vista local sobre o mundo, dificilmente conseguirá atingir um padrão de referência na mídia jornalística, a despeito do sucesso empresarial. Do segundo caso, o bairrismo apresentado como um critério de proximidade semelhante ao primeiro, pode tomar o perigoso caminho do etnocentrismo, como se a vida do cidadão da região de inserção do jornal valesse mais que a do cidadão de outra região, reproduzindo em parte a lógica dos critérios de noticiabilidade politicamente incorretos formulados, ironicamente, por um crítico de mídia do Village Voice e registrados por Moretzsohn (2002). Dentre eles, o crítico lembra que um editor não deve esquecer que há extensas partes do mundo nas quais as pessoas não existem a não ser em grupos de mais de 50 mil:

[...] A morte de um americano famoso pode sempre ser registrada, ainda que tenha ocorrido nas circunstâncias menos relevantes. Se o americano for um ilustre desconhecido, é preciso que morram pelo menos dois ou três [...]. No caso dos negros [americanos], o número tem de ser maior. Depois temos os europeus do sul (italianos, espanhóis, portugueses, gregos). Conte uns 30 deles para cada americano. Depois, os turcos, persas e latino-americanos. Conte uns 100 desses para cada americano [...]. Nessa altura já chegamos a um limite em números e passamos à categoria seguinte - a das hordas incalculáveis. São os indianos, africanos e chineses. Em relação a eles, já não se concebe qualquer número. As pessoas somente começam a se interessar se falarmos em 50 mil e 100 mil mortos. Especialistas calculam que somente uns 50 mil indianos seriam capazes de igualar, em termos de notícia, ao total de 10 americanos (Alexander Cockburn apud MORETZSOHN, 2002, p. 66).

Com esta citação, não se está a afirmar que Zero Hora, ao priorizar o regional e o local, esteja a enveredar pelo absurdo acima descrito. Apenas que tende a reproduzir lógica semelhante.

Tomemos agora mais dois "mandamentos": evitar o excesso de opinião e os textos longos. A recomendação é de que as matérias informativas tenham prioridade sobre os 
gêneros opinativos, e que estes devem ser preferencialmente de autores locais. "Se tiver que escolher entre um colunista da terra, ou uma estrela nacional, fique com o primeiro" (Rech apud Revista Imprensa, no 195, p. 60). Dos cerca de 55 autores de textos opinativos publicados regularmente em Zero Hora no período da análise (entre colunas, comentários, artigos, crônicas etc.), apenas dois não eram gaúchos - o sociólogo e ex-presidente Fernando Henrique Cardoso e o filósofo Olavo de Carvalho. A recomendação de se evitar o excesso de opinião, assim como os textos longos, que devem ser cortados ou transformados em gráficos, dá-se sob o argumento de não cansar o leitor, que deve, ao contrário, ser atraído para a leitura do jornal.

A preocupação em "agradar" o leitor é um dos dados mais evidentes coletados em todos os procedimentos de pesquisa adotados (observação participante, entrevistas, consulta a documentos, manuais, etc.). Aparece nas estratégias de marketing, de circulação, de venda de assinaturas, na flexibilidade dos cadernos, nas várias formas de entrega do produto, no tipo de treinamento oferecido aos jornalistas e aos funcionários dos serviços de apoio, no projeto gráfico e no projeto editorial. Dentre todas as recomendações de Marcelo Rech publicadas pela Revista Imprensa, a que aconselha "atender bem o leitor" é das mais representativas dessa política jornalístico-empresarial. Em Zero Hora, como se observou, o item faz parte dos programas de treinamento dirigidos a jornalistas. Tal é sua importância que uma editoria foi criada especificamente para atender as demandas dos leitores. A editoria também corresponde ao quesito interatividade, enunciado como um dos "pilares" da política editorial no congresso da WAN.

Dentre os esforços para agradar os públicos e ampliar a interlocução com eles, encontram-se as seções 'Cartas', 'Conselho do Leitor', 'O Rio Grande Pergunta', 'Sobre ZH' e serviços como 'Central de Atendimento ao Leitor' e 'Conselho dos Leitores'. São formas de incentivar e promover a comunicação entre emissor e receptor. $\mathrm{Na}$ coluna 'Conselho do Leitor', é publicado o resumo da reunião mais recente dos conselheiros, com elogios, críticas e sugestões. Os conselheiros são escolhidos anualmente entre voluntários que, teoricamente, representam vários tipos de público e se reúnem mensalmente com os editores. Exercem papel equivalente ao de um ombudsman de imprensa ao contrário - no lugar de o jornalista analisar o jornal em nome do leitor, este é quem faz a análise em nome 
de todos os leitores para o jornalista. O problema desse tipo de crítica é que o receptor da mensagem jornalística comenta o jornal segundo os parâmetros do senso comum - gosto disso, não gosto daquilo - desconhecendo os habitus da profissão e sem maior discussão das atribuições da imprensa jornalística na sociedade ${ }^{16}$.

A seção 'O Rio Grande Pergunta' contém sempre uma curiosidade, das mais prosaicas - "Qual a biografia da apresentadora Luciana Gimenez?” (ZH, 30/10/2004, p. 2) - às mais interessadas - "Quais as diferenças entre as tecnologias CDMA e GSM em telefones celulares?" ( $\mathrm{ZH}, 27 / 10 / 2004$, p. 2) ou "Como funciona o bafômetro" ( $\mathrm{ZH}$, 25/10/2004, p.2). Na mesma página, 'Sobre ZH' traz sempre um elogio ou uma crítica de leitor não integrante do Conselho sobre o tratamento dado pelo jornal ou por algum dos seus colunistas a determinado assunto.

Nessa interlocução, freqüentemente o jornal se justifica para o leitor. $\mathrm{Na}$ seção 'Cartas ao Leitor', publicada aos domingos, no dia 24 de outubro de 2004, o diretor de redação responde a leitores que reclamam da quantidade de anúncios nas páginas do jornal. Eles querem saber se isso não reduz o espaço das notícias.

Além dessas seções, a publicação dos nomes, dos telefones e dos endereços eletrônicos dos editores, assim como dos e-mails dos autores das matérias no final de cada texto, representa mais uma forma de estimular a interatividade. Assim, os leitores têm facilitado o contato para sugerir pautas, criticar abordagens ou simplesmente comentar os assuntos publicados. Quando o assinante liga para o Call Center para solicitar algum serviço, os atendentes estão orientados a perguntar se a edição do dia já foi lida e qual o assunto que mais chamou a atenção.

São estratégias de natureza editorial, que se somam às estratégias comerciais e mercadológicas, que estimulam o permanente contato do leitor com o veículo e vice versa. $\mathrm{Na}$ verdade, essas seções e serviços são apenas algumas das 55 formas ${ }^{17}$ empregadas pelo jornal com o objetivo de conhecer os seus públicos e de mantê-los satisfeitos.

\footnotetext{
16 Os conselheiros são escolhidos entre profissionais liberais, estudantes, professores, autônomos etc.

${ }^{17} \mathrm{O}$ levantamento é da editora-chefe Marta Gleich.
} 
Essa mistura de política editorial com estratégias de marketing pode ser desejável do ponto de vista dos objetivos da empresa. Da perspectiva jornalística, a indistinção de limites é controversa, no mínimo. O jornalismo, nos termos definidos anteriormente, que visa à publicização e ao debate dos temas de interesse público, transforma-se numa atividade com a finalidade de "servir ao público", o que representa uma significativa mudança de orientação. A citação abaixo auxilia-nos na defesa da hipótese de que esse tipo de jornalismo determina o declínio do conceito de notícia em favor de um jornalismo caracterizado pela prestação de serviço.

"Servir ao público" passa a ser uma atividade pautada por máximas de supermercado segundo as quais é preciso "servir bem para servir sempre", pois "o cliente tem sempre razão". Como mercadoria, a notícia deve ser oferecida de acordo com o gosto do freguês. E, evidentemente, a qualidade do produto passa a ser medida exclusivamente por esse padrão mercadológico: um jornal é bom simplesmente porque vende ou têm audiência (MORETZSOHN, 2002, p. 171).

O problema reside em tomar a circulação como parâmetro de aferição de qualidade jornalística, porque

O que faz um grande jornal é não só o que exprime de tiragem e receita publicitária, mas principalmente a sua opinião. É na linha editorial que repousam os sinais de credibilidade, confiança, identidade, firmeza, coerência, etc. (BAHIA, 1990, p. 242-242).

Optando pelo caminho descrito acima, Zero Hora circunscreve-se à tendência que acreditamos emergir, e se afasta do padrão de referência que se identifica numa publicação como O Estado de São Paulo. Em levantamento entre os jornais da chamada "grande imprensa" brasileira, Marques de Melo (2003) aponta o tradicional periódico paulista como o principal jornal de referência no Brasil e na América Latina. "O jornalismo de referência tem validade pública não apenas pelo reconhecimento que the tributam as elites dirigentes [...] ou as lideranças da sociedade civil, mas sobretudo pela função de agendamento informativo que exerce no interior do sistema midiático" (MARQUES DE MELO, 2003, p. 195). Segundo o autor, o caráter de referência restringe-se ao segmento de jornais diários que atuam como fontes de alimentação contínua da pauta de telejornais, radiojornais e webjornais. Define-se, assim, pela valorização dos acontecimentos que serão repercutidos 
nas outras mídias. Além de $O$ Estado de São Paulo, o autor classifica como de referência os jornais Folha de São Paulo, O Globo e Jornal do Brasil.

A partir de outro critério, Berger (1998) trabalha com outro tipo de classificação. A autora define $O$ Globo e Jornal do Brasil como de referência; e Jornal da Tarde e Folha de São Paulo como "nova imprensa" ou "imprensa de vanguarda". Aos de referência, atribui o papel de testemunhar o mundo produzindo um discurso universal e objetivável. Para estes, a informação jornalística seria concebida como fonte de conhecimento, de esclarecimento. À "nova imprensa" caberia produzir um discurso ligado ao "vivido", delegando a terceiros a tarefa de interpretar o mundo. "A Folha de São Paulo [...] traz articulistas intelectuais (internacionais) aos domingos para interpretar e refletir questões complexas do mundo atual que se manifestam, também, no Brasil” (BERGER, 1998, p. 46).

Quanto à Zero Hora, a pesquisadora não a enquadra nem como jornal de referência nem como "nova imprensa" ou "imprensa de vanguarda", porque no Rio Grande do Sul prevaleceria uma outra lógica no ordenamento dos jornais. Classifica-a como "jornal de referência dominante", uma vez que o caráter de referência determinado pelo critério prestígio seria, por tradição, do Correio do Povo. "É jornal de referência dominante por pertencer ao grupo RBS, que possui o canal de televisão afiliado à Rede Globo e, assim, detém um dos componentes de dominância no cenário da Comunicação no Brasill" (BERGER, 1998, p. 47).

Um jornal que tenha como objetivo manter-se de "rabo preso com o leitor" vez de servir de fonte de conhecimento, dificilmente tem liberdade, ou autonomia, para agendar temas que possam desagradar a segmentos de público. $O$ afastamento de comentaristas explicitamente contrários a um determinado partido político no Rio Grande do Sul é comentado "intramuros" na RBS como parte de um processo de "higienização", visando afastar a possibilidade de qualquer contrariedade com os leitores simpatizantes do partido em questão. Trata-se da implantação de uma política de evitar conflito, que representa a renúncia a uma das características intrínsecas à atividade jornalística. "O

\footnotetext{
18 Referência a slogan utilizado por algum tempo nas campanhas publicitárias da Folha de São Paulo.
} 
jornalismo é conflito, e quando não há conflito no jornalismo, um alarme deve soar", adverte-nos Bucci (2000, p. 11).

Dessa forma, a nova tendência, representada neste estudo por Zero Hora, pode estar a indicar a renúncia à análise, ou ao esclarecimento, que seria o resultado do trabalho de interpretação do jornalista expresso na unidade notícia, aqui tomada no sentido genérico, que inclui os gêneros reportagem e entrevista. "A notícia é um produto final de um processo no qual o jornalista age como árbitro [...]. É o que interpreta e seleciona os acontecimentos [...]" (Topping apud Mattos, 1995, p. 125).

O jornal em que a recomendação para atender bem o leitor, para fazer um noticiário local "com marola" - valorizando grandes momentos de pessoas comuns, investindo em micro-notícias sobre a vida da comunidade: "quem nasceu?", "quem morreu?", "o primeiro dia de aula da menina que tirou o aparelho dos dentes", etc. -, que recomenda investir no jovem porque, mesmo que ele não compre jornal hoje, amanhã será consumidor, é cúmplice e co-produtor da nova tendência. Promove um tipo de mudança que responde ao "modelo de soberania do leitor", que procura "legitimar-se através da oferta de uma interatividade plebiscitária do tipo 'você decide'.” (Moretzsohn, 2002, p. 172).

\section{Considerações finais}

O caráter de tendência configura-se na medida em que outras publicações começam a investir nessa concepção. Em entrevista à revista Imprensa, o ex-diretor de redação da revista $V_{e j a}$, Tales Alvarenga ${ }^{19}$, é instigado pelo entrevistador a comentar os resultados de pesquisa acadêmica em que a autora conclui pela desvinculação das revistas semanais de informação dos fatos marcantes da semana. A pesquisa foi realizada para uma tese de doutorado em que é demonstrado o recuo dos temas políticos e econômicos nas publicações do gênero em favor dos faits divers (saúde, moda, celebridades, escândalo, esquisitices, etc.). Ao responder se está de acordo ou não com a análise, o então diretor editorial do grupo Veja/Exame da Editora Abril argumenta que matérias sobre política não incrementam vendas, ao contrário das sobre comportamento, que sempre elevam as

\footnotetext{
${ }^{19}$ Tales Alvarenga foi diretor de redação de Veja entre 1998 e 2004.
} 
tiragens. "O fato é comprovado não só pelas pesquisas encomendadas aos institutos especializados, como pelo instinto. [...]. Conversando com as pessoas e sentindo sua reação" (Alvarenga apud revista Imprensa, no 195, p. 12). O título da tese da professora Maria Alice Carnevalli é sugestivo: "Indispensável é o leitor - o novo papel das revistas semanais de informação no Brasil”.

Um outro problema nessa política de sobretudo agradar ao leitor, para incrementar a circulação e, com isso, as receitas publicitárias, é de natureza ética. Tanto Tales Alvarenga quanto Marcelo Rech eram/são ${ }^{20}$ jornalistas e responsáveis por dar a linha editorial a veículos importantes de grandes conglomerados de comunicação. Nesse sentido, é-se obrigado a recorrer novamente a Bucci (2000, p. 24): “O jornalista não age para obter resultados que não sejam o de bem informar o público". Em razão disso, "ele não tem autorização ética para perseguir outros fins que não este [o de bem informar o público]".

$\mathrm{Na}$ nova concepção, jornais e revistas são tidos como meros veículos de informação, embora nem toda informação tenha atributos jornalísticos, como entretenimento e prestação de serviços. Transformam-se em "usinas de informação". Conforme Adghirni (2002), a idéia de jornal como “usina de informação" está associada ao declínio do conceito de notícia, em favor do conceito de informação, termo largamente adotado no jornalismo econômico e nos sistemas on-line, por influência dos professores da Universidade de Navarra. A expressão "informação" traduziria uma concepção e um modo de fazer jornalismo totalmente voltado para o mercado e às necessidades do "cliente" ou "usuário" - a nova denominação do leitor de notícias. Nessa perspectiva, o próprio jornalista é renomeado - transforma-se em "produtor de conteúdos"21.

A prevalecer como tendência hegemônica, numa conjuntura internacional marcada pela crescente oligopolização, processo que se manifesta fortemente no Brasil, pode significar uma ameaça aos próprios princípios da democracia liberal. À medida que privilegie os faits divers em detrimento da análise política, econômica, cultural, os conglomerados de mídia, oligopolistas em determinados mercados, monopolistas em

\footnotetext{
20 Tales Alvarenga faleceu no início de 2006.

${ }^{21}$ Coincidentemente essa é a expressão utilizada pela editora Marta Gleich para definir o perfil do jornalista multimídia perseguido pela RBS.
} 
outros, tendem a reproduzir apenas o ponto de vista das grandes corporações e dos segmentos hegemônicos ou mais organizados.

Para enfrentar a lógica flexível da etapa atual do capitalismo no mercado global, os conglomerados nacionais de comunicação associam-se a grupos do mercado financeiro internacional e tendem a se transformar em conglomerados transnacionais multimídia. A racionalidade determinada pela concentração de propriedade e pela aceleração do tempo de giro do capital se reproduz no âmbito das indústrias jornalísticas na forma de reestruturação da organização da produção e do trabalho. E deixa como conseqüência mudanças profundas, não só na aparência do jornal como nos valores sobre os quais se fundamenta o jornalismo.

\section{BIBLIOGRAFIA}

ADGHIRNI, Zélia Leal. Jornalismo on-line: em busca do tempo real. In: HOHLFELDT, Antonio; BARBOSA, Marialva (Orgs.). Jornalismo no século XXI: a cidadania. Porto Alegre: Mercado Aberto, 2002 (304-317).

BAHIA, Juarez. Jornal, história e técnica. São Paulo: Ática, 1990.

BERGER, Christa. Campos em confronto: a terra e o texto. Porto Alegre: Ed. da Universidade/UFRGS, 1998.

BARROS FILHO, Clóvis. Ética na Comunicação: da informação ao receptor. São Paulo: Moderna, 1995.

BOURDIEU, Pierre. Coisas Ditas. São Paulo: Brasiliense, 1990

BUCCI, Eugênio. Sobre ética e imprensa. São Paulo: Companhia das Letras, 2000.

CAPPARELLI, Sérgio. Zanzibar de novas tecnologias: imprensa regional e Zero Hora. In: Temas contemporâneos em comunicação. São Paulo: Edicon/Intercom, 1997 (109-126).

CASTELLS, Manuel. A Sociedade em Rede. $4^{\text {a }}$ ed. Rio de Janeiro: Paz e Terra, 2000a.

CHAPARRO, Manuel Carlos. Pragmática do jornalismo: buscas práticas para uma teoria da ação jornalística. São Paulo: Summus, 1994.

DARNTON, Robert. O beijo de Lamourette. São Paulo: Companhia das Letras, 1995. 
ERBOLATO, Mário L. Técnicas de codificação em jornalismo: redação, captação e edição no jornal diário. $5^{\text {a }}$ ed. São Paulo: Ática, 1991.

GENRO FILHO, Adelmo. O segredo da pirâmide: para uma teoria marxista do jornalismo. Porto Alegre: Ortiz, 1989. 230p.

HABERMAS, Jürgen. Mudança estrutural da esfera pública: investigação quanto a uma categoria da sociedade burguesa. $2^{\text {a }}$ ed. Rio de Janeiro: Tempo Brasileiro, 2003.

HARVEY, David. Condição pós-moderna: uma pesquisa sobre as origens da mudança cultural. $10^{\mathrm{a}}$ ed. São Paulo: Loyola, 2001.

HARVEY, David. A arte de lucrar: globalização, monopólio e exploração da cultura. In: MORAES, Denis (Org.). Por uma outra comunicação: mídia, mundialização cultural e poder. Rio de Janeiro/São Paulo: Record, 2003.

Manual da redação: Folha de São Paulo. $4^{\mathrm{a}}$ ed. São Paulo: Publifolha, 2001.

MARCONDES FILHO, Ciro. O capital da notícia: jornalismo como produção social de segunda natureza. São Paulo: Ática, 1989.

MARQUES DE MELO, José. História social da imprensa. Porto Alegre: EDIPUCRS, 2003.

2003.

Jornalismo brasileiro. Porto Alegre: Sulina,

MATTOS, Sérgio. Novas técnicas, tecnologias e tendências no jornalismo. In: Pauta Geral. Ano 3, vol. 3. Salvador: UFBA, 1995.

MORAES, Denis (Org.). Por uma outra comunicação: mídia, mundialização cultural e poder. Rio de Janeiro: Record, 2003.

MORETZSOHN, Sylvia. Jornalismo em "tempo real": o fetiche da velocidade. Rio de Janeiro: Revan, 2002.

REDE BRASIL SUL. Guia de Ética e Responsabilidade Social da RBS. Porto Alegre: RBS Publicações, 2004.

RÜDIGER, Francisco. Tendências do jornalismo. $3^{\mathrm{a}}$ ed. Porto Alegre: Ed. Universidade/UFRGS, 2003.

TASCHNER, Gisela. Folhas ao vento: análise de um conglomerado jornalístico no Brasil. Rio de Janeiro: Paz e Terra, 1992.

\section{ARTIGOS E/OU MATÉRIAS DE JORNAIS E REVISTAS}

Os dez mandamentos de Marcelo Rech. Revista Imprensa. São Paulo, p. 60-61, Ano 18, no 195, out. 2004. 
Crescimento de ZH é apresentado no congresso mundial de jornais. Zero Hora. Porto Alegre, p. 32, 02 jun. 2004.

Cartas ao Leitor. Zero Hora. Porto Alegre, p. 3, 24 out. 2004. 